\title{
Pemberian Konsentrat Mengandung Tepung Biji dan Kulit Durian Fermentasi terhadap Produksi dan Kualitas Susu serta MIOFC pada Sapi Perah
}

\section{Feeding Concenrate Containing Seed Powder and Fermented Rind of Durio zibethinus on Milk Production, Milk Quality and MIOFC of Dairy Cows}

\author{
E. Sulistyowati ${ }^{1}$, B. S. Priyono ${ }^{2}$, D. Titania ${ }^{1}$, Y. Setiaji ${ }^{1}$, dan A. Rahayu ${ }^{1}$ \\ ${ }^{1}$ Jurusan Peternakan, Fakultas Pertanian, Universitas Bengkulu \\ 2 Jurusan Agribisnis, Fakultas Pertanian, Universitas Bengkulu \\ Corresponding e-mail : ensulistyowati@yahoo.com
}

\begin{abstract}
The objective of this application was to evaluate concentrate containing durian seed meal and fermented durian rind meal on milk production, milk quality and milk income of feed cost (MIOFC) on dairy cows. Results of the application of concentrate containing durian seed meal produced highest milk $(8.93 \mathrm{l} / \mathrm{d})$ compared to other treatments. Concentrate containing durian seed meal required the lowest ration cost (Rp.17,507.35/d), gave the highest milk revenue (Rp.89,275.00/d) and the highest MIOFC (Rp.71,767.60/d). However the base ration was the efficient one since it didn't use concentrate therefor its ration cost was lower; while its milk yield was about the same as it was in concentrate containing durian seed meal.
\end{abstract}

Key words: durian seed meal, fermented durian rind meal, production, milk quality, MIOFC

\begin{abstract}
ABSTRAK
Tujuan dari aplikasi ini untuk mengevaluasi konsentrat mengandung tepung biji durian dan kulit durian fermentasi terhadap produksi dan kualitas susu serta milk income of feed cost (MIOFC) pada sapi perah. Hasil aplikasi pemberian konsentrat mengandung tepung biji durian menghasilkan produksi susu yang lebih tinggi (8,931/ekor/hari) dibanding perlakuan lainnya. Konsentrat dengan tepung biji durian membutuhkan biaya ransum terendah (Rp.17.507,35/ekor/hari), menghasilkan penerimaan susu tertinggi (Rp.89.275,00/ekor/hari) dan MIOFC tertinggi (Rp.71.767,60/ekor/hari). Namun, ransum dasar (tanpa konsentrat tepung biji durian dan kulit durian fermentasi) tetap yang efisien karena tidak menggunakan konsentrat sehingga biaya ransum lebih rendah; sementara, produksi susu hampir sama dengan konsentrat tepung biji durian.
\end{abstract}

Kata kunci: tepung biji durian, kulit durian fermentasi, produksi, kualitas susu, MIOFC

\section{PENDAHULUAN}

Untuk memenuhi proses produksi susu, pada peternakan sapi perah rakyat diperlukan ketersediaan pakan yang cukup dan berkesinambungan. Pakan yang biasanya tersedia di sekitar lokasi peternakan di desa Mojorejo, Selupu Rejang, Rejang Lebong, Bengkulu adalah rumput lapangan dan sebagian kecil rumput Gajah (Pennisetum purpureum) yang ditanam oleh peternak. Peternak jarang memberikan pakan tambahan seperti konsentrat. Bahan pakan penyusun konsentrat bisa berasal dari limbah pertanian dan perkebunan yang tersedia di sekitar, seperti limbah buah durian.

Produksi buah durian di Provinsi Bengkulu sekitar 11.555 ton (Dirjen Hortikultura, 2018). Potensi limbah durian adalah biji 1.155 ton/tahun dan kulit durian sebanyak 7.510,52 ton/tahun. Biji durian dapat dikonversi menjadi tepung biji durian sebesar 225 ton dan kulit durian dapat dikonversi menjadi tepung kulit durian (bagian dalam berwarna putih) adalah 43,26\% atau 2.276,9 ton/tahun (Sulistyowati et al., 2019 ). Biomassa tepung kulit durian ini perlu difermentasi dengan Pleurotus ostreatus (jamur Tiram) sedangkan biji durian perlu dibuat tepung untuk meningkatkan kecernaan nutrisi sehingga berpotensi untuk dimanfaatkan sebagai pakan ternak ruminansia, termasuk sapi dan kambing perah.

Selain karena keterbatasan pengetahuan peternak akan penggunaan bahan limbah pertanian (seperti biji dan kulit durian) yang potensial untuk digunakan sebagai pakan konsentrat atau blok pakan (sebagai sumber energi) juga karena dianggap menambah biaya pakan. Padahal penggunaan konsentrat akan 
meningkatkan produksi susu yang pada akhirnya meningkatkan pendapatan (milk income over feed cost $=$ MIOFC). Buza et al. (2014) menyimpulkan bahwa kombinasi antara biaya hijauan yang agak tinggi dan biaya yang ransum yang tinggi akan menghasilkan produksi susu yang tinggi dan MIOFC yang juga tinggi; sebaliknya biaya ransum yang kecil belum tentu menghasilkan produksi susu dan MIOFC yang tinggi.

Biaya pakan dengan konsentrat mengandung limbah durian lebih rendah sebesar Rp. 667,90/ekor/hari (Sulistyowati et al., 2020a) dan biaya pakan sebesar $48,41 \%$ dari penerimaan susu (Sulistyowati et al., 2019a. Secara ekonomis, pemanfaatan KDF 20\% dilaporkan menghasilkan nilai Milk Income over Feed Cost (MIOFC) sapi perah Fries Holland (FH) yang lebih tinggi daripada level KDF 10 atau 30\%. Hal ini sesuai dengan tingkat produksi susu yang juga tertinggi pada level tersebut sehingga penerimaan dari susu juga tinggi. Harga konsentrat yang juga lebih rendah dibanding penggunaan $\mathrm{KDF} 10 \%$, juga mengurangi biaya ransum total (Sulistyowati et al., 2019a). Pemanfaatan 5\% KDF dalam konsentrat untuk kambing perah laktasi adalah optimal dengan menghasilkan produksi susu tertinggi 1,56 1/ekor/hari dengan nilai MIOFC tertinggi sebesar Rp. 17.648,20/ekor/ hari, dibandingkan pada perlakuan $10 \%$ dan $20 \% \mathrm{KDF}$. Adapun nilai $\mathrm{B} / \mathrm{C}$ adalah 0,63 sedangkan nilai BEP sebesar 0,75 (Sulistyowati et al., 2020ª).

Pada sapi perah pemberian konsentrat mengandung $20 \%$ tepung kulit durian fermentasi menghasilkan produksi susu tertinggi, 10,8 1/ekor/hari dengan nilai MIOFC tertinggi sebesar Rp. 39.183/ekor/ hari (Sulistyowati et al., 2019ª). Level optimal 5\% dengan MIOFC tertinggi pada kambing perah (Sulistyowati et al., 2020 ). Konsentrat dengan kulit durian fermentasi 30\% dilaporkan tidak menganggu kondisi fisiologis sapi perah (Sulistyowati et al., 2019d). Pemberian konsentrat yang mengandung $27,5 \%$ tepung biji durian merupakan level optimal untuk produksi susu, efisiensi produksi susu dan kualitas susu

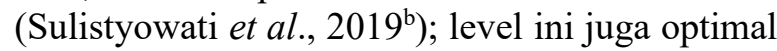
untuk kecernaan nutrisi in vivo pada sapi perah (Sulistyowati et al., 2019ª).

Berdasarkan beberapa hasil penelitian diatas, telah dilakukan evaluasi produksi dan kualitas susu serta analisis MIOFC dari aplikasi konsentrat yang mengandung tepung biji durian dan kulit durian fermentasi pada sapi perah.

\section{MATERI DAN METODE}

\section{Pembuatan Tepung Biji Durian (TBD)}

Biji durian dicuci, dirajangtipis dengan menggunakan alat pengasah terbuat dari kayu, selanjutnya dijemur dengan sinar matahari hingga kering, kemudian digiling dan diayak menjadi tepung biji durian (Sulistyowati et al., 2019 ${ }^{\mathrm{b}}$ ).

\section{Pembuatan Kulit Durian Fermentasi (KDF)}

Pengolahan kulit durian fermentasi dimulai dari pembuangan kulit duri luar, kulit dalam berwarna putih kemudian diiris tipis, dikeringkan di bawah sinar matahari hingga mudah dipatahkan, kemudian digiling dua kali untuk mendapatkan tepung kulit durian. Tahap selanjutnya adalah proses fermentasi. Tepung kulit durian sebanyak $85 \%$, dedak padi $13 \%$ dan $2 \% \mathrm{CaCO} 3$ dicampur dengan $90 \%$ air, dikomposkan selama 2 × 24 jam selanjutnya ditimbang $600 \mathrm{~g}$ dan dimasukkan dalam baglog. Setelah itu disterilisasi selama $120^{\circ} \mathrm{C}$ selama 4 jam, kemudian didinginkan pada suhu sekitar $40^{\circ} \mathrm{C}$ diinokulasi dengan $0.5 \%$ Pleurotus ostreatus (Sulistyowati et al., 2018).

\section{Penyusunan Konsentrat- TBD -KDF}

Penyusunan formula ketiga macam konsentrat ini merupakan modifikasi dari Sulistyowati et al. $\left(2019^{c}\right)$ untuk kandungan KDF dan Sulistyowati et al. (2018) untuk kandungan TBD. Formula dan harga bahan konsentrat disajikan pada Tabel 1.

\section{Pemberian Konsentrat - TBD- KDF}

Aplikasi atau pemberian ransum dengan konsentrat yang mengandung TBD dan atau KDF pada sapi perah laktasi dilakukan dengan Rancangan Kelompok 4 x 4 dan data yang ditabulasi kemudian dianalisis varians atau Anova (Lentner and Bishop, 1986). Ada 4 perlakuan dan 4 ulangan, total sapi perah laktasi yang digunakan ada 4 ekor dengan waktu aplikasi selama 4 periode, masing- masing 10 hari, dengan masa pendahuluan selama 10 hari, total 50 hari. Perlakuan yang diaplikasikan adalah:

K0 : Ransum dasar peternak sebagai kontrol

$\mathrm{K} 1$ : Ransum dasar peternak sebagai kontrol +2 $\mathrm{kg}$ Konsentrat TBD

K2 : Ransum dasar peternak sebagai kontrol +2 $\mathrm{kg}$ Konsentrat KDF

K3 : Ransum dasar peternak sebagai kontrol +2 kg Konsentrat TBD-KDF 
Tabel 1. Komposisi dan harga konsentrat mengandung tepung durian dan kulit durian fermentasi

\begin{tabular}{|c|c|c|c|c|c|c|c|}
\hline Bahan & $\begin{array}{c}\text { Komposisi } \\
(\%) \\
\text { TBD }\end{array}$ & $\begin{array}{c}\text { Komposisi } \\
(\%) \\
\text { KDF }\end{array}$ & $\begin{array}{c}\text { Komposisi } \\
(\%) \\
\text { TBD+KDF }\end{array}$ & $\begin{array}{c}\text { Harga } \\
(\mathrm{Rp} / \mathrm{kg})\end{array}$ & $\begin{array}{c}\text { Nilai } \\
(\mathrm{Rp} / \mathrm{kg}) \\
\text { TBD }\end{array}$ & $\begin{array}{c}\text { Nilai } \\
(\mathrm{Rp} / \mathrm{kg}) \\
\text { KDF }\end{array}$ & $\begin{array}{c}\text { Nilai } \\
(\mathrm{Rp} / \mathrm{kg}) \\
\text { TBD+KDF }\end{array}$ \\
\hline Dedak padi & 30 & 30 & 10 & $2.500,00$ & 750 & 750 & 250 \\
\hline TBD & 27,5 & $\mathbf{0}$ & 27,5 & $1.500,00$ & 412,5 & 0 & 412,5 \\
\hline $\mathrm{KDF}$ & $\mathbf{0}$ & 20 & 20 & $2.400,00$ & 0 & 480 & 480 \\
\hline Jagung giling & 14,5 & 22 & 14,5 & $7.000,00$ & 1015 & 1540 & 1015 \\
\hline Kedelai giling & 18 & 18 & 18 & $9.500,00$ & 1710 & 1710 & 1710 \\
\hline Minyak sawit & 3,5 & 3,5 & 3,5 & $14.000,00$ & 490 & 490 & 490 \\
\hline Mineral Mix & 0,5 & 0,5 & 0,5 & $8.000,00$ & 40 & 40 & 40 \\
\hline Temulawak & 1 & 1 & 1 & $45.000,00$ & 450 & 450 & 450 \\
\hline Ragi Tape & 1 & 1 & 1 & $23.000,00$ & 230 & 230 & 230 \\
\hline $\mathrm{NaCl}$ & 0,5 & 0,5 & 0,5 & $10.000,00$ & 50 & 50 & 50 \\
\hline $\mathrm{CaCO} 3$ & 1 & 1 & 1 & $4.000,00$ & 40 & 40 & 40 \\
\hline TSP & 0,5 & 0,5 & 0,5 & $10.000,00$ & 50 & 50 & 50 \\
\hline Urea & 2 & 2 & 2 & $2.500,00$ & 50 & 50 & 50 \\
\hline Total & 100 & 100 & 100 & & 5287,5 & 5880 & 5267,5 \\
\hline \multicolumn{8}{|c|}{ Kandungan Nutrisi (\%) } \\
\hline Protein kasar & 23,92 & 29,70 & 26,78 & & & & \\
\hline
\end{tabular}

Pengukuran variabel produksi dan kualitas susu serta MIOFC data hasil aplikasi Konsentrat- TBD- KDF

Variabel yang dievaluasi adalah:

a. Konsumsi bahan kering dan produksi susu ditimbang dan diukur tiap hari dan efisiensi produksi susu (Sulistyowati et al., 2018); kualitas susu dianalisis kandungan nutrisi pada $2 \times$ pemerahan (sore dan pagi) terakhir (Sulistyowati et al., 2020 ).

b. Analisis ekonomi, harga konsentrat $/ \mathrm{kg}$, biaya ransum, harga susu, penerimaan dari susu, pendapatan dari susu setelah biaya pakan (MIOFC) menurut Sulistyowati et al. $\left(2019^{\mathrm{a}}\right)$.

\section{HASIL DAN PEMBAHASAN}

Pengukuran volume produksi susu dilakukan selama aplikasi perlakuan konsentrat dengan TBD dan KDF seperti pada Tabel 2 berikut ini. Walaupun tidak terdapat perbedaan yang signifikan $(\mathrm{P}>0,05)$, namun rataan produksi susu tertinggi terdapat pada perlakuan dengan konsentrat TBD (8,93 1/ekor/hari). Ini lebih tinggi 0,3 1/ekor/hari dibanding ransum tanpa konsentrat dan sekitar 1,5 1/ekor/hari lebih tinggi dibanding perlakuan dengan konsentrat KDF dan kombinasinya.

Produksi susu pada aplikasi ini lebih rendah dibanding produksi susu sapi perah dengan konsentrat mengandung 20\% KDF dilaporkan tertinggi (11,19 1/ekor/hari) dibanding KDF 10 dan 30\% pada penelitian sebelumnya di peternakan yang berbeda menurut Sulistyowati et al. $\left(2020^{\mathrm{b}}\right)$. Hal ini disebabkan fase laktasi yang sudah melewati masa puncak produksi pada beberapa sapi perah yang digunakan dalam aplikasi ini. Namun, secara keseluruhan produksi susu pada aplikasi konsentrat yang mengandung KDF atau kombinasi KDF dan TBD memang lebih rendah daripada konsentrat TBD. Produksi susu dengan TBD juga lebih tinggi dibandingkan ransum dasar (RD) yang tidak mendapat konsentrat.

Tabel 2. Produksi susu sapi perah yang diberi konsentrat mengandung tepung biji durian dan kulit durian fermentasi

\begin{tabular}{lcccc}
\hline Periode & RD & TBD & KDF & TBD+KDF \\
\hline I & & $----1 /$ ekor/hari & --- & \\
II & 4,66 & 5,75 & 7,86 & 9,01 \\
III & 10,70 & 5,08 & 5,78 & 10,27 \\
IV & 12,48 & 12,48 & 4,94 & 6,17 \\
Rataan & 6,71 & 12,40 & 10,90 & 4,32 \\
\hline Keta & 8,64 & 8,93 & 7,37 & 7,44 \\
\hline
\end{tabular}

Keterangan: Tidak terdapat perbedaan yang signifikan antarperlakuan $(\mathrm{P}>0,05)$ 
Ini menunjukkan bahwa tepung biji durian dengan kandungan karbohidrat mudah tercerna (readiable carbohydrate, RAC) yang tinggi menjadi sumber energi sebagai prekursor produksi susu (Larson, 1985).

Kandungan protein yang rendah $(23,92 \%)$ namun RAC tinggi pada konsentrat TBD menghasilkan produksi susu yang lebih tinggi dibanding kedua konsentrat yang mengandung KDF walaupun protein kasarnya lebih tinggi. Berarti, bahan pakan dengan sumber RAC yang lebih tinggi akan menghasilkan susu yang lebih tinggi dibanding bahan yang mengandung serat kasar lebih tinggi walaupun kandungan protein kasarnya lebih tinggi. Adapun kandungan protein kasar ketiga konsentrat ini (Tabel 1) melebihi kandungan protein kasar yang direkomendasikan untuk produksi susu antara 6,80- 12,65 1/ekor/hari adalah 12- 15\% (NRC, 1989). Selanjutnya kandungan nutrisi konsentrat akan menentukan kualitas susu, dapat dilihat pada Tabel 3.

Konsentrat TBD menghasilkan lemak susu tertinggi; namun, kandungan SNF (solid non fat), BJ, laktosa, dan protein serta temperatur lebih rendah dibandingkan pada susu sapi perah yang diberi konsentrat yang mengandung KDF atau ransum dasar atau tanpa konsentrat. Lemak susu merupakan hasil metabolisme karbohidrat yang mengandung serat kasar (structured carbohydrate). Namun, hasil lemak susu dengan konsentrat yang mengandung KDF tidak menunjukkan hasil yang lebih tinggi, sebaliknya, lebih rendah dibanding lemak susu dari sapi perah yang mendapat konsentrat TBD. Kualitas susu juga dipengaruhi konsumsi nutrisi yang terkandung dalam ransum seperti disajikan pada Tabel 4.

Konsumsi ransum yang terdiri atas hijauan, konsentrat TBD, KDF dan kombinasi keduanya, ampas tahu dan solid sawit antarperlakuan tidak berbeda nyata. Namun, sapi perah dengan konsentrat TBD mengkonsumsi hijauan lebih tinggi $(2,23 \mathrm{~kg} / \mathrm{ekor} / \mathrm{hari})$. Hal ini tampak menghasilkan lemak susu yang lebih tinggi dibanding konsentrat KDF, walaupun tidak konsisten dengan lemak susu yang dihasilkan dari konsentrat dengan kombinasi TBD-KDF yang mempunyai konsumsi hijauan yang lebih tinggi. Kandungan protein lemak susu yang lebih tinggi pada sapi perah dengan konsentrat KDF dan kombinasi TBD- KDF tampaknya merupakan cerminan dari kandungan protein kasar dari konsentrat yang mengandung kulit durian fermentasi (KDF) yang memang lebih tinggi setelah difermentasi (Sulistyowati et al., 2020b). Disamping itu, konsumsi solid sawit yang lebih tinggi (sekitar $1 \mathrm{~kg} / \mathrm{ekor} / \mathrm{hari}$ ) pada konsentrat KDF dan kombinasinya, mengandung protein kasar yang juga tinggi $(17,13 \%)$ menurut Yanto dan Febrina (2008).

Biaya ransum dengan konsentrat KDF tampak lebih tinggi dibanding biaya ransum dengan konsentrat TBD atau kombinasinya serta biaya ransum dasar (Table 5). Tingginya biaya ransum ini berasal dari lebih tingginya komposisi jagung giling dalam konsentrat dibanding konsentrat lainnya. Oleh karena itu, kandungan protein kasar konsentrat $\mathrm{KDF}$ ini juga tertinggi $(29,70 \%)$. Hal ini berarti harga protein kasar kurang lebih sebesar Rp. 198,97 untuk setiap satu persennya.

Tabel 3. Kualitas susu sapi perah yang diberi konsentrat mengandung tepung biji durian dan kulit durian fermentasi

\begin{tabular}{lcccc}
\hline Variabel & RD & TBD & KDF & TBD +KDF \\
\hline Lemak (\%) & 3,32 & 3,47 & 2,78 & 2,81 \\
SNF $(\%)$ & 7,42 & 6,32 & 7,16 & 7,41 \\
BJ & 1,03 & 1,02 & 1,03 & 1,03 \\
Laktosa $(\%)$ & 4,07 & 3,47 & 3,93 & 4,07 \\
Protein $(\%)$ & 2,71 & 2,31 & 2,62 & 2,71 \\
Temperatur $\left({ }^{\circ} \mathrm{C}\right)$ & 28,48 & 27,41 & 27,57 & 28,56 \\
\hline
\end{tabular}

Tabel 4. Rataan konsumsi ransum sapi perah yang diberi konsentrat mengandung tepung biji durian dan kulit durian fermentasi

\begin{tabular}{|c|c|c|c|c|}
\hline \multirow{2}{*}{ Bahan ransum } & $\mathrm{RD}$ & TBD & $\mathrm{KDF}$ & $\mathrm{TBD}+\mathrm{KDF}$ \\
\hline & \multicolumn{4}{|c|}{ 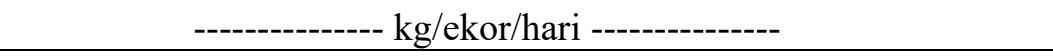 } \\
\hline Hijauan & 28,15 & 26,65 & 24,42 & 30,07 \\
\hline Konsentrat & 0 & 2,0 & 2,0 & 2,0 \\
\hline Ampas Tahu & 1,9 & 1,84 & 2,0 & 2,0 \\
\hline Solid sawit & 8,66 & 9,34 & 10,46 & 10,28 \\
\hline
\end{tabular}


Tabel 5. Biaya ransum sapi perah yang diberi konsentrat mengandung tepung biji durian dan kulit durian fermentasi

\begin{tabular}{|c|c|c|c|c|}
\hline \multirow{2}{*}{ Bahan ransum } & $\mathrm{RD}$ & TBD & $\mathrm{KDF}$ & $\mathrm{TBD}+\mathrm{KDF}$ \\
\hline & \multicolumn{4}{|c|}{--------------- Rp/ekor/hari --------------- } \\
\hline Hijauan & $3.518,75$ & $3.331,25$ & $3.052,50$ & $3.758,75$ \\
\hline Konsentrat & 0 & $10.595,00$ & $11.780,00$ & $10.555,00$ \\
\hline Ampas tahu & $2.375,00$ & $2.296,85$ & $2.500,00$ & $2.500,00$ \\
\hline Solid & $1.190,75$ & $1.284,25$ & $1.438,25$ & $1.413,50$ \\
\hline Total & $7.084,50$ & $17.507,35$ & $18.770,75$ & $18.227,25$ \\
\hline
\end{tabular}

Tabel 6. Rataan penerimaan dari susu dan MIOFC sapi perah yang diberi konsentrat mengadung tepung biji durian dan kulit durian fermentasi

\begin{tabular}{lcccc}
\hline \multirow{2}{*}{ Variabel } & RD & TBD & KDF & TBD + KDF \\
& & ----------- Rp/ekor/hari & ----------- & \\
\hline Penerimaan & $86.375,00$ & $89.275,00$ & $73.700,00$ & $74.425,00$ \\
MIOFC & $79.290,50$ & $71.767,60$ & $54.929,25$ & $56.197,75$ \\
\hline
\end{tabular}

Harga ini lebih dalam kisaran yang cukup ekonomis mengingat harga komersial sekitar Rp. 200 untuk setiap satu persen kandungan protein kasar. Adapun harga konsentrat KDF ini adalah Rp. 5880/kg. Harga ini lebih tinggi dibanding harga di pasaran, namun kandungan nutrisinya produk komersial ini belum diketahui sesuai standar.

Penerimaan dari susu tertinggi dihasilkan pada konsentrat TBD (Tabel 6) sesuai dengan tingkat produksi susu yang dihasilkan (Tabel 2). Pada saat yang sama, biaya ransum pada perlakuan TBD paling rendah dibanding konsentrat KDF dan kombinasinya. Oleh karena itu, pendapatan dari susu atau milk income over feed cost (MIOFC) pada perlakuan konsentrat TBD juga tertinggi (Rp.71.767,60/ekor/hari) atau Rp. 1960,50/1.

\section{KESIMPULAN}

Hasil aplikasi pemberian konsentrat mengandung tepung biji durian menghasilkan produksi susu yang lebih tinggi 8,931/ekor/hari dibanding produksi susu sapi perah dengan konsentrat yang mengandung kulit durian fermentasi baik secara tunggal dan kombinasi keduanya. Konsentrat dengan tepung biji durian membutuhkan biaya ransum terendah (Rp. 17.507,35/ekor/hari), menghasilkan penerimaan tertinggi (Rp.89.275,00/ekor/hari) dan milk income of feed cost (MIOFC) tertinggi (Rp. 71.767,60/ekor/hari) dibanding kedua konsentrat lainnya yang mengandung kulit durian fermentasi. Namun, ransum dasar (tanpa konsentrat tepung biji durian dan kulit durian fermentasi) tetap yang efisien karena biaya ransum lebih rendah.

\section{UCAPAN TERIMAKASIH}

Penelitian ini terlaksana atas dana Pengabdian Berbasis Riset dari Universitas Bengkulu dengan nomor kontrak: SP DIPA023.017.2.677529/2020. Untuk itu Tim menyampaikan penghargaan yang setinggitingginya. Kepada Pak Mursalim (Ketua) dan para Anggota Kelompok Tani Sepakat II dan para petugas di peternakan sapi perah, Mas Budi dan Mas Alex di desa Mojorejo, kecamatan Selupu Rejang, kabupaten Rejang Lebong, propinsi Bengkulu kami menyampaikan terima kasih atas kerjasamanya dalam kegiatan ini. Terimakasih juga disampaikan kepada Ahmad Fauzi, dan Bintang S. Mandala, Sistanto, SPt., MSi, Dirgandaru G. Waskito, S.Hub. Int'1., Gilang D. Waseso, SP., Riko Herdiansah, SPt., MP., Rubi J. Waspodo, Nurul Khotimah, SPt, dan Rina Sumardani, SPt. yang telah membantu dalam pelaksanaan kegiatan ini.

\section{DAFTAR PUSAKA}

Buza, M. H. L.A. Holden, R. A. White, and V. A. Ishler. 2014. Evaluating the effect of ration composition on income over feed cost and milk yield. J. Dairy Sci. 97 (5) : 3073-3080.

Dirjen Hortikultura. 2018. Produksi Durian Menurut Provinsi, 2013- 2017. www.pertanian.go.id. Diakses 23Juni2019.

Larson, B.L. 1985. Lactation. The Iowa State Univ. Press. Ames. IA.

Lentner, M. and T. Bishop. 1986. Experimental Design and Analysis. Valley Book Co. VA. 
National Research Council. 1989. Nutrient Requirements of Dairy Cattle (6th ed.). Washington, D.C: National Academy Press.

Sulistyowati, I. Badarina, and S. Mujiharjo. 2018. Milk Production and Feed Efficiency of Dairy Cow Fed Concentrate Containing Durian Peel Flour Fermented with Pleurotus ostreatus. The 4th International Seminar on Animal Industry Bogor, August 28-30, 2018. Pp: 86-90.

Sulistyowati, E., Jarmuji, I. Badarina, S. Mujiharjo, T. Akbarillah, dan B. Al Iman. 2019. Pemanfaatan Kulit Durian Difermentasi Pleurotus ostreotus dalam Konsentrat Sapi Perah terhadap Pendapatan. Prosiding: Seminar Nasional Pengentasan Kemiskinan."Potret Pengentasan Kemiskinan di Indonesia: Tantangan, Strategi, dan Capaian" 24 Juli 2019 di Hotel Santika, Kota Bengkulu. Hal: 228- 232.

Sulistyowati, E., E. Soetrisno, S. Mujiharjo, D. E. Lorence, E. Gustia, and S. Meisella. 2019 ${ }^{\mathrm{b}}$. Milk Production and Quality of Dairy Cow Fed Diet Containing Concentrate with Durian Murr Seed Flour. 6th International Conference on Sustainable Agriculture, Food and Energy. Manila, The Philippines. In IOP Conference Series: Earth and Environmental Science (Vol. 347, No. 1, p. 012011). IOP Publishing. Doi:10.1088/1755-1315/347/1/012011.

Sulistyowati, E., I. Badarina, S. Mujiharjo, T.Simbolon, and I. R. Purba. 2019 . Diet with Concentrate Containing Durio zibethinus Murr Seed Meal: Nutrient Contents, Fatty Acid Profiles, In Vitro Characteristics, and Nutrient Digestibility in Dairy Cows. Buletin of Animal Science 43 (4): 218-224. Doi: 10.21059/buletinpeternak.v43i4.44606.

Sulistyowati, E., D. Suherman, I. Badarina, S. Mujiharjo dan S. Fanhar. 2019d. Respon Fisiologis Sapi Fries Holland Laktasi yang Diberi Ransum dengan Konsentrat Mengandung Kulit Durian Difermentasi Pleorotus ostreatus. Jurnal Sain Peternakan Indonesia 14 (1): 101- 112. Doi.10.31186/jspi.id.14.1.101-112.

Sulistyowati, E., I. Badarina, S. Mujiharjo, R. Mariska, dan E. Khoirul. 2020 ${ }^{\mathrm{a}}$. Analisis Ekonomis Penggunaan Tepung Kulit Durian Fermentasi dalam Konsentrat untuk Kambing Perah. Jurnal Sain Peternakan Indonesia. $15 \quad$ (1): $\quad 29-\quad 36$. Doi.10.31186/jspi.id.15.1.37-42.

Sulistyowati, E., I. Badarina, S. Mujiharjo, Sistanto, I. R. Dhani, R. Putri, E. Terimasari, A. Proyogi, B. Al Iman, and S. Fanhar. $2020^{\mathrm{b}}$. Performance of dairy cows fed diet containing concentrate with fermented Durian peel. Jurnal Ilmu-Ilmu Peternakan 30 (1): 29- 39. DOI: 10.21776/ub.jiip.2020.030.01.0.

Yanto, K. dan D. Febrina. 2008. Potensi Lumpur Sawit (Solid) sebagai Pakan Ruminansia di Kabupaten Pelalawan Provinsi Riau. Agripet. 8 (2): 35-41. 